https://doi.org/10.18485/iipe_postkovid.2021.ch13

\title{
KOVID 19 - REMETILAČKI ČINILAC U BLIŽEM POVEZIVANJU EVROPSKE UNIJE SA REGIONOM ZAPADNOG BALKANA
}

\author{
Miloš PETROVIĆ ${ }^{1}$ \\ Vladimir VUČKOVIĆ2
}

\begin{abstract}
Apstrakt: Širi tematski kontekst rada ogleda se u proklamovanoj potrebi Evropske komisije za snažnijim geopolitičkim angažmanom, posebno u geografski, društvenoistorijski i ekonomski bliskim državama iz jugoistočne Evrope. Premda autori navode da Evropska unija (EU) godinama unapređuje odnose sa tim zemljama pomoću instrumenata iz politike proširenja, pored izazova u evropeizaciji regiona u poslednjih nekoliko godina beleži se i pojačano prisustvo drugih geopolitičkih aktera, što nije bilo blagotvorno za međusobno unapređivanje odnosa. Uprkos spomenutim, kao i drugim brojnim međunarodnim izazovima za Evropsku uniju, autori rada smatraju da je EU usvajanjem izmenjene metodologije za pristupne pregovore za tzv. zapadnobalkanske države demonstrirala političku volju kako bi doprinela unapređenju odnosa. Međutim, kako autori polemišu, vanredne epidemiološke okolnosti koje su usledile počevši od prvog kvartala 2020. godine potisnule su aktivnosti u domenu politike proširenja ka periferiji interesovanja ne samo evropskih, već i institucija u regionu, te se postavlja pitanje na koji način se Kovid 19 pandemija manifestovala na odnose sa Zapadnim Balkanom. Autori smatraju da se tok Kovid 19 pandemije nepovoljno odrazio na političke odnose između Evropske unije i njenih kandidata za članstvo u neposrednom i posrednom smislu. Služeći se analizom sadržaja i teorijskim konceptom evropeizacije, autori identifikuju nepovoljne političke uticaje pandemije, koje obrazlažu na nekoliko nivoa: 1. prolongiranje podrške
\end{abstract}

\footnotetext{
${ }^{1}$ Naučni saradnik, Institut za međunarodnu politiku i privredu, Beograd. E-mail: milos.petrovic@diplomacy.bg.ac.rs.

Rad je nastao u okviru naučnoistraživačkog projekta „Srbija i izazovi u međunarodnim odnosima 2021. godine", koji finansira Ministarstvo prosvete, nauke i tehnološkog razvoja Republike Srbije, a realizuje Institut za međunarodnu politiku i privredu tokom 2021. godine.

2 Predavač, Fakultet društvenih studija, Univerzitet „Masarik“, Brno, Češka Republika. E-mail: vuckovic@mail.muni.cz.
} 
Evropske unije u prevazilaženju posledica pandemije, koje se negativno odrazilo na njenu meku moć i kredibilitet, ali i pružilo dodatan prostor za delovanje drugih aktera; 2 . nedostatak fokusa i pasivnost institucija u pojedinim zemljama regiona u smislu produbljivanja preobražajnih demokratskih procesa, i 3. odsustvo povoljnih rezultata u smislu valorizacije političkog napretka zapadnobalkanskih zemalja ka članstvu u EU, što je vidljivo i na osnovu sadržaja Zagrebačke deklaracije i neusvajanja zaključaka Evropskog saveta u domenu politike proširenja.

Ključne reči: izmenjena metodologija politike proširenja, Evropska unija, kandidati za članstvo, Kovid 19, izazovi, evropeizacija, Zapadni Balkan

\section{Uvod}

U agendi aktuelnog saziva Evropske komisije (inaugurisane 2019. godine) nalazi se više političkih prioriteta: od ekologije i doprinosa borbi protiv klimatskih promena, preko digitalizacije i unapređenja tržišta rada, do geopolitički prisutnije Unije pod geslom „Snažnija Evropa u svetu“. ${ }^{3}$ Svest o potrebi za snažnijim geopolitičkim angažmanom proistekla je iz brojnih međunarodnih izazova sa kojima se Unija suočila u pogledu transatlantskog partnerstva tokom predsedničke administracije Donalda Trampa, narušenih odnosa sa Ruskom Federacijom, postupka Bregzita, promatranja razvoja odnosa sa Kinom, ali i uticaja drugih aktera na području Zapadnog Balkana, regiona koji već dve decenije nastoji da produbi svoju povezanost sa geografskim susedima u Evropskoj uniji. ${ }^{4}$

U toku poslednjih nekoliko godina nije zabeležen očekivani napredak državakandidata ka članstvu u Evropskoj uniji. lako je u junu 2018. Evropska komisija preporučila otvaranje pristupnih pregovora sa Severnom Makedonijom i Albanijom, ni do kraja 2019. godine Savet Evropske unije nije podržao početak pristupnih pregovora s tim zemljama pre redefinisanja metodologije pristupnog procesa. ${ }^{5} \mathrm{Na}$

\footnotetext{
${ }^{3}$ Ursula Von Den Leyen, A Union that strives for more - My agenda for Europe, European Commission, Brussels, 2019, Internet: https://ec.europa.eu/info/sites/info/files/politicalguidelines-next-commission_en_0.pdf, 18/02/2021.

${ }^{4}$ Stefan Lehne, "Geopolitics, the EU and the Western Balkans", in: Zoran Nechev (ed), Stimulating strategic autonomy-Western Balkans' contribution for a shared European Future, Institute for Democracy Societas Civilis, Skopje, 2020, pp. 17-18.

${ }^{5}$ Council of the European Union, Presidency conclusions on Enlargement and Stabilisation and Association Process - Albania and the Republic of North Macedonia, Luxembourg, 15
} 
inicijativu Francuske i uz podršku drugih članica, početkom 2020. godine na nivou Unije usvojena je izmenjena metodologija politike proširenja, u nastojanju da se unaprede performanse i instrumenti te politike. Izmenjeni deo pristupne metodologije nastoji da prevaziđe manjkavosti prethodnog pristupa fokusiranjem na nekoliko domena, poput unapređenja verodostojnosti pristupnog procesa, pojačanog uključivanja političkih elita, ukrupnjavanja pregovaračkih oblasti u tzv. tematske klastere i većoj transparentnosti i predvidivosti procesa. ${ }^{6}$ Usvajanje izmenjene metodologije, prema mišljenju autora ovog rada, predstavljalo je adekvatan korak u unapređenju procesa koji je usled birokratskih i političkih aspekata godinama stagnirao. Evropska unija pokazala je političku spremnost da revidira svoj raniji pristup, čije su manjkavosti otežavale produbljivanje odnosa sa tzv. zapadnobalkanskim zemljama.

Međutim, revidirani metod politike proširenja faktički nije imao pogodan momenat da profunkcioniše, budući da su vanredne prilike izazvane pandemijom Kovid 19 - koje su usledile već od prvog kvartala 2020. godine planove i aktivnosti u domenu politike proširenja potisnule ka periferiji interesovanja nacionalnih i nadnacionalnih institucija. Premda je u martu 2020. godine, tokom hrvatskog predsedavanja Savetom Evropske unije, načelno podržano otvaranje pristupnih pregovora sa Albanijom i Severnom Makedonijom, ni godinu dana kasnije nije određen datum za održavanje prve međuvladine konferencije, tj. faktičko stupanje u pregovore. ${ }^{7}$ Razlog tome je neusvajanje pregovaračkih platformi za te zemlje od strane nadležnih evropskih institucija, o čemu će biti više reči u kasnijem segmentu rada.

Geslo „Snažnija Evropa u svetu“ i geostrateški planovi suočeni su sa novim izazovima, a očuvanje javnog zdravlja postalo je nacionalni i međunarodni prioritet, što se odrazilo na sve domene društvenog i privrednog života. Imajući to u vidu, autori će nastojati da odgovore na pitanje - na koji način se Kovid 19 pandemija posredno i nesporedno manifestovala na domen evropskih integracija država tzv. Zapadnog Balkana. Nepovoljne političke uticaje pandemije

October 2019, Internet: https://data.consilium.europa.eu/doc/document/ST-13155-2019INIT/en/pdf, 30/01/2021.

6 "Enhancing the accession process - A credible EU perspective for the Western Balkans", European Commission (COM(2020) 57 final), Brussels, 5.2.2020, pp. 2-5.

7 Goran Bandov, "Croatia's EU Presidency: A strong Europe in a world of challenges", European View, vol. 19, no. 2, 2020, p. 192. 
autori nastoje da objasne pomoću teorijskog koncepta evropeizacije i putem analize sadržaja. Multidimenzionalni negativni uticaji mogu se analizirati na više nivoa: 1. prolongiranje podrške Evropske unije u prevazilaženju posledica pandemije, koje se negativno odrazilo na njenu „meku moć“ i kredibilitet, ali i pružilo dodatan prostor za delovanje drugih aktera; 2 . manjak strateškog fokusa i pasivnost institucija u pojedinim zemljama regiona u smislu produbljivanja preobražajnih demokratskih procesa, i 3. odsustvo povoljnih rezultata u smislu valorizacije političkog napretka zapadnobalkanskih kandidata ka članstvu u EU. Sadržaj dokumenata iz 2020. poput izveštaja o napretku, Zagrebačke deklaracije, pa i neusvajanja zaključaka Evropskog saveta u domenu politike proširenja, podupiru stav da u pandemijskoj godini ne samo da nije bilo vidljivog napretka na evropskom putu zemalja regiona, već i da perspektiva pristupanja deluje čak i dalje nego što je to bio slučaj pre aktuelne krize, o čemu će biti podrobnije diskutovano u narednim delovima rada.

Usvajanjem revidirane metodologije politike proširenja uoči evropske pandemijske krize stvorene su pretpostavke za dalji razvoj i izoštreniji fokus pristupne agende. Međutim, pred kandidatima predstoji izazovan period produbljivanja reformskih procesa u okolnostima kada Kovid 19 predstavlja globalni izazov po zdravlje i perspektivu razvoja. Pandemijska kriza dvostruko je nepovoljno uticala na evropske integracije Zapadnog Balkana: prvo - pažnja Evropske unije skrenuta je sa politike proširenja (i to tokom prvog predsedavanja Hrvatske Evropskim savetom, kada je pristupna agenda trebalo da zauzme značajnije strateško mesto); drugo - dodatno su otežani uslovi za sprovođenje zahtevnih sveobuhvatnih reformi u zapadnobalkanskim državama (koje inače imaju ograničene ekonomske i političke demokratske performanse), a od njih se očekuje da preobražajne procese nastave u okolnostima epidemiološke krize bez presedana. Navedene stavke, nažalost, ne pružaju povoda za posebno optimistične prognoze i vode zaključcima da je pandemijski kontekst već rezultovao odlaganjima i poremećajima u sprovođenju planova politike proširenja, što se negativno odrazilo na evropske integracije zemalja Zapadnog Balkana.

\section{Teorijski okvir: neveliki dometi evropeizacije Zapadnog Balkana}

Proces evropskih integracija na Zapadnom Balkanu moguće je tumačiti kroz teorijski okvir evropeizacije, čije se delovanje u kontekstu ovog rada vezuje za organizacionu i administrativnu moć Evropske unije, i na primenu tih uticaja na 
oblikovanje nacionalnih političkih i ekonomskih sistema. ${ }^{8}$ Takođe, pored proceduralnog dela koji se odnosi na oblikovanje institucija, evropeizacija se može analizirati i na osnovu šireg konteksta, načina na koji su evropske norme, vrednosti i institucije ugrađene u politički narativ, i kako to doprinosi integraciji (ili dezintegraciji). ${ }^{9}$ Međutim, reformski procesi na Zapadnom Balkanu odvijaju se u drugačijem kontekstu u odnosu na prethodne cikluse „istočnih proširenja“ - ne samo da oni nisu vremenski oročeni, već su podvrgnuti i dodatnim uslovima u okviru procesa stabilizacije i pridruživanja. ${ }^{10}$ Razlike tu ne prestaju ohrabrivanje procesa evropeizacije otpočelo je u ranijim fazama pripremljenosti za članstvo zemalja Zapadnog Balkana spram srednjoevropskih država-članica Evropske unije, te se napredak u sprovođenju reformi rigoroznije meri ne samo u poslednjoj fazi pristupnih pregovora, već i u pretpristupnoj fazi. ${ }^{11} \mathrm{U}$ kontekstu sve ranije i obuhvatnije potrebe za preobražajem, u slučaju Zapadnog Balkana povremeno se govori kao o pristupu „evropeizacije putem proširenja“. ${ }^{12}$ Proces evropeizacije povezuje se sa izvesnošću dobijanja podsticaja od Evropske unije u slučaju sprovođenja reformi, uz princip uslovljavanja kao instrument za ohrabrivanje neophodnih reformskih aktivnosti. ${ }^{13}$ Takođe je važno napomenuti i da je još od sednice Evropskog saveta u Kopenhagenu, pre bezmalo tri decenije, aspekt „apsorpcionih kapaciteta“ Unije da primi nove članice jedan od legitimnih argumenata Evropske unije za podešavanje dinamike rundi proširenja u zavisnosti od prilika u samoj Uniji. ${ }^{14}$ Kako bi Evropska unija prevazišla „zamor od proširenja“, prema tom argumentu, nužno je da protekne izvesno vreme i budu preduzete odgovarajuće mere kako bi se poboljšale smanjene performanse evropskih institucija i politika.

${ }^{8}$ John Borneman \& Nick Fowler, "Europeanization", Annual Review of Anthropology, vol. 26, 1997, pp. 488-489.

${ }^{9}$ Mary Murphy, "The Brexit crisis, Ireland and British-Irish relations: Europeanisation and/or de-Europeanisation?" Irish Political Studies, vol. 34, no. 4, 2019, p. 532.

${ }^{10}$ Miloš Petrović, „Izmenjena politika proširenja: izazovi i koncentrični krugovi integracije”, Međunarodni problemi, vol. LXXI, no. 1/2019, 2019, str. 54-55.

${ }^{11} \mathrm{lbid}$.

${ }^{12}$ Spyros Economides \& James Ker-Lindsay, "Pre-Accession Europeanization': The Case of Serbia and Kosovot", Journal of Common Market Studies, vol. 53, no. 5, 2015, p.1029.

${ }^{13}$ Gergana Noutcheva \& Senem Aydin-Düzgit, "Lost in Europeanisation: The Western Balkans and Turkey", West European Politics, vol. 35, no. 1, 2012, p. 59.

${ }^{14}$ Maja Kovačević, Evropska diferencirana unija, Fakultet političkih nauka, Beograd, 2020. str. 143. 
Međutim, dok se proces evropeizacije vezuje za koncept „učenja“, primene evropskih normi i savladavanja izazova u cilju adekvatnijeg funkcionisanja institucija, koji ne prestaje samim činom pristupanja u Uniju, postupnost i dugotrajnost procesa proširenja na Zapadnom Balkanu čini da se najpre sam čin članstva vidi kao cilj, umesto onih prava, privilegija i obaveza koje će uslediti kao posledica pristupanja. ${ }^{15}$ To je moguća posledica prolongiranog pristupnog toka, koji je čak i u slučaju „najmlađe“ države-članice, Hrvatske, trajala duže nego u slučaju drugih zemalja Srednje i Istočne Evrope. Hrvatska je ne samo prva zemlja koja je bila podvrgnuta proširenim kriterijumima u pogledu procesa stabilizacije i pridruživanja, već i među onima gde se situacija u pogledu vladavine prava u pojedinim periodima pred pristupanje pogoršavala. ${ }^{16} \mathrm{U}$ okviru „zapadnobalkanskog ciklusa" politike proširenja, jedino je Hrvatska, prema proceni evropskih institucija i država-članica, uspela da u dovoljnoj meri zadovolji kriterijume članstva kako bi pristupila Uniji (uz definisanje određenih prelaznih rokova kojim su privilegije članstva privremeno ograničene, poput npr. mogućnosti za države-članice da najduže sedam godina ograničavaju pristup hrvatskih radnika svojim tržištima rada). ${ }^{17} \mathrm{U}$ izveštaju Evropske komisije o stanju vladavine prava iz 2020. godine, „najmlađa“ država Evropske unije rangirana je među poslednjim članicama u pogledu percepcije nezavisnosti pravosuđa, uz brojne manjkavosti u pravnom okviru, kao i primeni antikoruptivnih zakona. ${ }^{18} \mathrm{Na}$ osnovu hrvatskog primera može se konstatovati da proces evropeizacije ne prestaje činom pristupanja, već podrazumeva kontinuirani angažman koji se odvija i uporedo sa članstvom. S druge strane, u slučaju zemalja Zapadnog Balkana dolazi do sve prisutnijeg prožimanje pojmova „proširenja“ i „evropeizacije“, gde se drugi navedeni koncept više ne povezuje primarno sa postupnim preuzimanjem normi i obrazaca, niti na preobražaju,

${ }^{15}$ Spyros Economides \& James Ker-Lindsay, "Pre-Accession Europeanization': The Case of Serbia and Kosovot", Journal of Common Market Studies, vol. 53, no. 5, 2015, p. 1030.

${ }^{16}$ Gergana Noutcheva \& Senem Aydin-Düzgit, "Lost in Europeanisation: The Western Balkans and Turkey", West European Politics, vol. 35, no. 1, 2012, p. 63.

${ }^{17}$ European Commission, Croatia's accession to the European Union - Q\&A, European Commission, Brussels, 2013, Internet: https://ec.europa.eu/commission/presscorner/ detail/de/MEMO_13_629, 13/02/2021.

${ }^{18}$ European Commission, 2020 Rule of Law Report - Country Chapter on the rule of law situation in Croatia, European Commission, Brussels, 2020, Internet: EUR-Lex 52020SC0310- EN- EUR-Lex (europa.eu), 15/03/2021. 
pa ni nekim nivoom „evropskog identiteta“, već najpre u „ispunjavanju uslova za članstvo u Evropskoj uniji“. ${ }^{19}$ Dok su kriterijumi članstva, pa i sam birokratski proces, sve zahtevniji za kandidate za članstvo, prema mišljenju autora ovog rada, možda je upravo takva logika doprinela udaljavanju od suštine koja počiva na preobražaju i stvaranju održivog, evropeizovanog sistema. Pojedini autori koriste i sintagmu "balkanizacije umesto evropeizacije“ kako bi opisali nemogućnost kandidata sa Zapadnog Balkana da primene evropske standarde u domenima poput reforme pravosuđa i antikoruptivnih praksi. ${ }^{20}$ To je odraz višestrukih slabosti zapadnobalkanskih država, od ograničenja u uspostavljanju državnosti, preko nedovoljno razvijenih administrativnih kapaciteta, do uloge „veto igrača“ i ograničene političke moći samih institucija. ${ }^{21}$

$\mathrm{Na}$ tragu takvih razmišljanja, usvajanje izmenjene metodologije politike proširenja EU usmereno je ne samo ka omogućavanju formalnog stupanja u pristupne pregovore sa Severnom Makedonijom i Albanijom, već i unapređenje perspektive za evropeizaciju, tj. za preoblikovanje sistema u državamakandidatima u skladu sa evropskim tekovinama. Novi metod počiva na neophodnosti unapređenja kredibilnosti pristupnog procesa, potrebi za snažnijom političkom odgovornošću tj. angažmanom političkih elita, uvođenju sistema „klasterizacije" tematskih poglavlja i naglaska na jačoj transparentnosti i predvidivosti. Pored toga, veći je fokus na instrumentu reverzibilnosti tj. nazadovanja u pristupnim pregovorima kao unapređenom alatu politike proširenja (koji je kao mogućnost postojao i ranije). ${ }^{22}$ Taj je instrument u ranijim ciklusima proširenja predstavljao posredniji vid negativnog uslovljavanja nego što to deluje da će biti slučaj u aktuelnoj izmenjenoj metodologiji. Primera radi, u slučaju istočnih proširenja, pojedine zemlje su izdvajane u grupe sporije

\footnotetext{
${ }^{19}$ Spyros Economides \& James Ker-Lindsay, "Pre-Accession Europeanization': The Case of Serbia and Kosovot", op. cit., p. 1030.

${ }^{20}$ Vladimir Vučković, Mira Popović \& Daliborka Uljarević (ur.), Balkanizacija umesto evropeizacije: borba protiv korupcije u Crnoj Gori, Friedrich Ebert Stiftung, Podgorica, 2020, str. 4-15. Takođe: Vladimir Vučković, Mira Popović \& Siniša Gazivoda (eds.), Dug put do pravde: reforma pravosuđa u Crnoj Gori, Friedrich Ebert Stiftung, Podgorica, 2020, str. 5-17.

${ }^{21}$ Tanja Börzel, "When Europeanization Hits Limited Statehood - The Western Balkans as a Test Case for the Transformative Power of Europe", KFG Paper series, no. 30, 2011, pp. 8-9.

22 Maja Kovačević, „Politika proširenja Evropske unije u potrazi za reformom“, Politička revija, no. 2/2020, 2020, str. 140.
} 
napredujućih ka članstvu u EU, kao što je npr. bio slučaj sa Bugarskom i Rumunijom, koje su propustile „prvi talas“ istočnih proširenja i prednosti koje su proisticale iz ranijeg članstva. ${ }^{23}$ Međutim, u međuvremenu je, pored ostalih brojnih izmena, došlo i do snažnijeg opredeljenja Evropske unije za primenu principa diferencijacije, koji se ogleda u logici regate i valorizaciji pojedinačnih zasluga, što se pokazalo već u narednom (i poslednjem) ciklusu proširenja kada je Uniji pristupila samo Hrvatska. ${ }^{24} \mathrm{U}$ slučaju pregovora sa Srbijom i Crnom Gorom uvedeno je pravilo da, ukoliko dođe do ozbiljnog udaljavanja od evropskih normi i vrednosti, na inicijativu Komisije ili jedne trećine zemalja članica može doći i do obustavljanja pregovora i uslovljavanja njihovog nastavka, uz kvalifikovanu većinu Saveta Evropske unije. ${ }^{25}$

Dok negativno uslovljavanje odlikuje proces evropskih integracija na Zapadnom Balkanu od najranijih faza i vidljivije je nego ranije, s druge strane, aspekt pozitivnog uslovljavanja i podsticaja sve se manje opaža i deluje da su koristi indirektnije i teže dostupne nego ranije. ${ }^{26}$ Prema modelu spoljnih podsticaja kojim se podstiču aktivnosti u okviru procesa evropeizacije, kredibilitet uslovljavanja je ključan - s jedne strane je nužno da uslovi budu što precizniji i mogućnost sankcije izvesnija, ali je isto tako neophodno da obim očekivane nagrade i njena izvesnost budu značajni i primereni nivou negativnog uslovljavanja. ${ }^{27}$ I autori ovog rada smatraju da reverzibilnost predstavlja primereni mehanizam za uvećanje efikasnosti principa uslovljavanja, posebno u slučaju značajnog nazadovanja u nekom aspektu reformi i pogoršanja parametara demokratije i slobodne privrede. Međutim, važno je da primena tog alata bude usklađena i sa poboljšanjem drugih performansi revidirane

${ }^{23}$ Gergana Noutcheva \& Senem Aydin-Düzgit, "Lost in Europeanisation: The Western Balkans and Turkey", op. cit., p. 59.

${ }^{24}$ Ibid., pp. 63-64.

${ }^{25}$ Maja Kovačević, „Politika proširenja Evropske unije u potrazi za reformom“, op. cit., str. 145.

${ }^{26}$ Miloš Petrović, "EU integration process of Serbia: a vicious circle of high politics?" The Review of International Affairs, vol. LXX, no. 1175, 2019, p. 25. Konsultovati: Asya, Zhelyazkova et al., "European Union Conditionality in the Western Balkans: External Incentives and Europeanisation", in: Jelena Dzankic, Soeren Keil \& Marko Kmezić (eds.), The Europeanisation of the Western Balkans - A Failure of EU Conditionality?, Palgrave Macmillan, 2019, pp. 15-37.

${ }^{27}$ Maja Kovačević, „Politika proširenja Evropske unije u potrazi za reformom“, op. cit., str. 136-137. 
metodologije, prvenstveno sa vidljivijim podsticajima, kako bi ceo proces bio izvesniji i verodostojniji. Drugim rečima, pored akademski prepoznatog „zamora od proširenja“, neophodno je da se prepozna i otklanja problem „zamora od pristupanja" u zemljama obuhvaćenim aktuelnom politikom proširenja. ${ }^{28}$ Obe vrste posustajanja, u kombinaciji sa višegodišnjim fokusiranjem pažnje Evropske unije na domen stabilnosti pre nego na produbljivanje reformskih procesa, a posebno u odsustvu kredibilne perspektive članstva u Evropskoj uniji, doprinele su očuvanju stabilokratskih i neliberalnih tendencija u zemljama regiona. Pored toga, angažman drugih međunarodnih aktera političkim elitama u regionu omogućio je produbljivanje saradnje na način koji nije uvek usklađen sa strateškim ciljem pristupanja u Evropsku uniju, što je u određenim situacijama otežavajuće za dostizanje evropskih standarda u određenim oblastima. ${ }^{29}$

Povrh već konstatovanih izazova, eskalacija Kovid 19 pandemije dodatno je otežala kandidatima za članstvo da unaprede funkcionisanje ključnih domena evropskih integracija, poput izgradnje nezavisnih institucija, borbe protiv korupcije i unapređenja širokog opsega prava i sloboda za građane i privredu. Pored toga, organizovanje izbora u zemljama poput Srbije, Crne Gore, pa i Severne Makedonije, koji su sprovedeni u toku pandemije, pokazali su da evropske integracije zauzimaju manje istaknuto mesto u političkom diskursu nego što je to bio slučaj ranije. Osim toga što u 2020. godini nisu načinjeni krupni koraci u pogledu evropeizacije regiona, a što je barem delimično posledica pandemije, kontekst za sprovođenje reformi dodatno je unazađen nemogućnošću Unije da vidljivije pomogne partnerima na Zapadnom Balkanu u prevazilaženju krize. S druge strane, akteri koji su iz perspektive Evropske unije već godinama ekonomski i politički prisutniji u regionu, poput NR Kine, Ruske Federacije i Sjedinjenih Američkih Država, u pojedinim su periodima delovali angažovanije u zapadnobalkanskim državama nego što je to EU kojoj te zemlje nastoje da pristupe. Da se pored javnog zdravlja ipak radi i o strateškom domenu, svedoči i izjava ministra za inovacije i tehnološki razvoj Republike Srbije da bi proizvodnjom Sputnjk V cepiva na svojoj teritoriji država „obnovila suverenitet u proizvodnji

${ }^{28}$ Andrea Frontini \& Davide Denti, "Italy and EU enlargement to the Western Balkans: the Europeanization of national interests?", Southeast European and Black Sea Studies, vol. 17, no. 4, 2017, p. 575.

${ }^{29}$ Vladimir Vučković \& Vladimir Đorđević (eds.), Balkanizing Europeanization: Fight against corruption and regional relations in the Western Balkans, Peter Lang, Berlin, 2019, pp. 29-30. 
vakcina“, što će ubuduće „biti sve važnija oblast u ostvarivanju geopolitičke ravnoteže u svetu".$^{30} \mathrm{U}$ tom smislu, težnja za jačim geopolitičkim prisustvom Evropske unije (koje bi ohrabrilo i posustali proces evropeizacije regiona) barem se delimično pokazalo neuspešnom, s obzirom na to da su drugi spomenuti akteri zapravo delovali prisutnije u regionu nego što je to bio slučaj pre pandemije.

\section{Force mejeure i poremećaji u sprovođenju agende politike proširenja}

Vanredne epidemiološke okolnosti, koje su usledile počevši od prvog kvartala 2020. godine, potisnule su sprovođenje mera u domenu politike proširenja ka periferiji interesovanja kako državnih ustanova širom kontinenta tako i nadnacionalnih institucija Evropske unije. Odvijanje Kovid 19 pandemije nepovoljno se odrazilo i na političke odnose između Evropske unije i njenih kandidata za članstvo. Ti se uticaji na političke procese mogu analizirati na nekoliko nivoa: 1. neblagovremena podrška Evropske unije u prevazilaženju posledica pandemije, posebno u ranom stadijumu krize, što se odrazilo na njenu „meku moć“ i kredibilnost na Zapadnom Balkanu; 2. preokupljenost pojedinih zapadnobalkanskih zemalja i drugim procesima, poput sprovođenja izbora, uz nedovoljan fokus na sprovođenju reformi u takvim okolnostima; 3. izostanak političkog napretka zemalja regiona ka članstvu u Evropskoj uniji, uprkos usvajanju revidirane metodologije politike proširenja.

Prvo - u Evropskoj uniji je izostalo solidarnosti tokom pandemijske krize, i to ne samo prema kandidatima za članstvo. Podrška evropskih institucija pojedinim državama-članicama takođe je bila neblagovremena i neprimerena. Iz Italije, najvećeg evropskog žarišta korona virusa u početnoj fazi pandemije, premijer Đuzepe Konte hitno je zatražio dostavljanje zaštitne i medicinske opreme za bolničko osoblje, ali danima nije bilo reakcije ni od evropskih institucija, ni od država-članica, što je kasnije dovelo do zvaničnog izvinjenja Evropske komisije zbog neblagovremene i nedovoljne reakcije. ${ }^{31}$ Pored neadekvatne reakcije Unije,

\footnotetext{
${ }^{30}$ Slobodna Evropa, Popović: Preliminarno odobrena proizvodnja ruske vakcine u Srbiji, Radio Slobodna Evropa, 2021, Internet: https://www.slobodnaevropa.org/a/popovi\%C4\%87preliminarno-odobrena-prva-faza-proizvodnje-ruske-vakcine-u-srbiji/31099930.html, 19/02/2021.

${ }^{31}$ BBC, Coronavirus: EU offers 'heartfelt apology' to Italy, BBC, London, 2020, Internet: https://www.bbc.com/news/world-europe-52311263, 20/03/2021.
} 
zabeleženi su i odnosi nadmetanja među državama-članicama, a umesto kriznog planiranja na nivou nadnacionalnih evropskih institucija sve su primetnije bile bilateralne tendencije. Tako su brojne evropske zemlje nastojale da obezbede vlastite zalihe zaštitnih alata i zdravstvenih sredstava, dok su neke druge zaustavile izvoz medicinskih sredstava. ${ }^{32}$ Ne samo da je Evropska unija privremeno ograničila izvoz spomenutih artikala izvan svojih granica, što je izazvalo negativne reakcije u državama-kandidatima za članstvo, već su i među njenim članicama zabeleženi primeri da se međusobno onemogućuje izvoz te opreme, bez obzira na njihovu pripadnost jedinstvenom evropskom tržištu. ${ }^{33}$ Pored političkih, zabeleženi su i ekonomski poremećaji usled naglog zatvaranja granica i ograničavanja prekograničnog saobraćaja, što je otežalo i inače izazovnu distribuciju medicinske i zaštitne opreme, kao i druge robe. Kandidati za članstvo su u okolnostima izostanka blagovremene podrške od EU i zabrane izvoza opreme potražili pomoć od drugih aktera. Srbija je među prvima produbila humanitarno-diplomatske odnose sa Kinom, od koje je od samog početka krize dobijala vrednu pomoć u medicinskoj i drugoj opremi. ${ }^{34} \mathrm{~S}$ druge strane, Evropska unija je usled svog neadekvatnog delovanja bila suočena sa svojevrsnom „PRkrizom" na Zapadnom Balkanu. ${ }^{35}$ Primera radi, svega oko $16 \%$ naslova u srpskim medijima koji su se ticali EU tokom prve pandemijske godine imalo je pozitivnu konotaciju, u poređenju sa više od $36 \%$ negativnih i $47 \%$ neutralnih naslova. ${ }^{36}$

Nestašica pojedinih proizvoda ne samo da je uticala na percepciju o izvesnoj samodovoljnosti Unije kao ekonomske sile, već je i podstakla protekcionističko ponašanje u regionu koji se decenijama razvijao upravo prevazilaženjem

${ }^{32}$ Richard Grey, Lack of solidarity hampered Europe's coronavirus response, research finds, Horizon Magazine, 2020, Internet: https://horizon-magazine.eu/article/lack-solidarityhampered-europe-s-coronavirus-response-research-finds.html, 20/03/2021.

${ }^{33}$ Ibid., Konsultovati: "Commission Implementing Regulation (EU) 2020/402 of 14 March 2020 making the exportation of certain products subject to the production of an export authorisation", Official Journal of the European Union, vol. 63, no, L 077 I.

${ }^{34}$ Government of the Republic of Serbia, China donates two coronavirus laboratories to Serbia, Belgrade, 2020, Internet: https://www.srbija.gov.rs/vest/en/153617/chinadonates-two-coronavirus-laboratories-to-serbia.php, 19/02/2021.

${ }^{35}$ Vladimir Milić, Serbia's Balancing Act on China, Choice, 2020, Internet: https://china observers.eu/serbias-balancing-act-on-china/, 10/02/2021.

${ }^{36}$ Savet za stratešku politiku, „Spoljnopolitičke posledice KOVID-19 krize po Srbiju“, Beograd, 2021, str. 9. 
prekograničnih prepreka i slobodnom protoku robe, kapitala i usluga. Pored toga što je početak krize bio obeležen manjkom solidarnosti u EU, taj se fenomen ponovo uočljivo ispoljio s početkom procesa masovne imunizacije stanovništva odobrenim vakcinama protiv Kovid 19. Dok se taj proces u prvim mesecima 2021. godine odvijao vrlo usporeno na nivou čitave Unije (ali i uz znatne regionalne razlike), postoje indicije da su određeni farmaceutski proizvođači pojedinačnim državama-članicama nudili brži pristup vakcinama po višim cenama, preko treće strane. ${ }^{37}$ Pored činjenice da EU nije bila uspešna u blagovremenom pribavljanju cepiva za stanovnike koji žive na njenoj teritoriji u početnoj fazi masovne imunizacije, ni njene ambicije da pomogne geografskim susedima nisu se ostvarile s početkom 2021. godine. Kovaks (CoVax) sistem, koji je uspostavljen uz podršku Unije, u prvim mesecima imunizacije još uvek nije profunkcionisao, a većina zapadnobalkanskih zemalja proces vakcinisanja stanovništva ili još uvek nije otpočela ili je ostvarila simbolične pomake. Pojedini analitičari čak polemišu o „konstantnoj tragediji“ Zapadnog Balkana kao periferije, koja niti pripada Evropskoj uniji, niti se smatra prioritetnim područjem za Kovaks (s obzirom na to da se radi o srednje razvijenim zemljama u globalnim okvirima koje ne spadaju među države koje vakcine ne mogu da priušte). ${ }^{38}$

Izuzetak predstavlja Srbija koja je na osnovu međudržavnog/bilateralnog ugovaranja nabavki sa kineskim, ruskim i američko-nemačkim proizvođačima uspela da pribavi veliki broj cepiva i da prilično rano i dinamično otpočne proces masovne imunizacije, ubrajajući se među vodeće zemlje po stopi vakcinisanih spram broja stanovnika, što je bila i logika pojedinih drugih zemalja. ${ }^{39}$ Međutim, tokom istog perioda, multilateralne inicijative, uključujući i one na nivou EU, nisu pokazale zadovoljavajuće rezultate. Pored toga, države iz jugoistočne Evrope su ugovaranjem isporuka medicinske opreme i cepiva iz Kine i Rusije - zemalja koje

${ }^{37}$ EurActiv Network, Four EU leaders were offered 'separate' deals with AstraZeneca, 2021, EurActiv, Internet: https://www.euractiv.com/section/politics/news/four-eu-leaders-wereoffered-separate-deals-with-astrazeneca/, 10/02/2021.

${ }^{38}$ Ivana Kottasová, Caught in a vaccine no man's land, these European countries are scrambling for Chinese and Russian shots, WRAL/CNN, 2021, Internet: https://www.wral. com/caught-in-a-vaccine-no-mans-land-these-european-countries-are-scrambling-forchinese-and-russian-shots/19535385/, 19/03/2021.

${ }^{39}$ Reid Standish, China's Strategic Vaccine Diplomacy Gains A Foothold In The Balkans, Radio Free Europe Radio Liberty, 2021, Internet: https://www.rferl.org/a/china-strategic-vaccinediplomacy-gains-a-foothold-in-the-balkans/31106320.html, 10/03/2021. 
EU percipira za svoje geostrateške rivale na tom prostoru - uspostavile bliže kontakte i unapredile odnose sa spomenutim državama. U tom smislu, namera Evropske komisije da se region Zapadnog Balkana na geopolitičkom planu dodatno poveže sa Unijom ne samo da nije uspeo u 2020. godini, već su njeni strateški takmaci na jugoistoku Evrope čak i prisutniji nego ranije.

Drugo - od početka eskalacije pandemijske krize, kandidati za članstvo u Evropskoj uniji nisu produbljivali reforme u planiranom obimu ni dinamici, a ni izmenjena metodologija politike proširenja faktički nije profunkcionisala. Izveštaji o napretku kanidata za članstvo zabeležili su skromne rezultate ili stagnaciju u domenima poput vladavine prava, unapređenja osnovnih sloboda, reforme pravosuđa, medijskih sloboda, borbe protiv korupcije. ${ }^{40}$ Pored pandemije, važan razlog za taj nepovoljni ishod predstavlja činjenica da je u većem delu regiona - u Srbiji, Severnoj Makedoniji, Crnoj Gori, Bosni i Hercegovini - 2020. bila izborna godina. ${ }^{41}$ Pored toga što intenzitet sprovođenja reformskih aktivnosti često opada tokom izbornih godina, čak i sami izbori su u svim spomenutim državama održani sa kašnjenjem, prvenstveno kao posledica pandemije (Srbija, Crna Gora, Severna Makedonija) ili usled zastoja u usvajanju nacionalnog budžeta (Bosna i Hercegovina). ${ }^{42} \mathrm{U}$ zemljama koje važe za "vodeće kandidate“, kontekst evropskih integracija umesto jedne od dominantnih tema zauzimao je periferan položaj u političkom diskursu spram identitetskih pitanja (Crna Gora), i ekonomije i unutarpolitičkih tenzija sa brojnim opozicionim strankama koje su bojkotovale izbore (Srbija). ${ }^{43}$ Evropska komisija konstatovala je niz zamerki u pogledu sprovođenja izbornih procesa i

40 "2020 Communication on EU enlargement policy", European Commission (COM(2020) 660 final), Brussels, 6. October 2020, pp. 4-10.

${ }^{41} \mathrm{U}$ Republici Srbiji parlamentarni, pokrajinski i lokalni izbori održani su 21.06.2020; u Severnoj Makedoniji parlamentarni izbori su organizovani 15.07.2020; u Crnoj Gori parlamentarni i (delimični) lokalni izbori sprovedeni su 30.08.2020, a u Bosni i Hercegovini lokalni izbori su održani 15.11.2020. godine.

42 Nikolaos Tzifakis, "The Western Balkans during the pandemic: Democracy and rule of law in quarantine?" European View, vol. 19, no. 2, 2020, p. 203; Aida Đugum, Lokalni izbori u BiH pomjereni na 15. novembar, nejasnoće oko datuma, Radio Slobodna Evropa, 2020, Internet: https://www.slobodnaevropa.org/a/lokalni-izbori-bih-odgodjeni-cik/30630248. html, 10/01/2021.

43 "2020 Communication on EU enlargement policy", European Commission (COM(2020) 660 final), Brussels, 6. October 2020, p. 11. 
šire političke atmosfere i u Srbiji i u Crnoj Gori u svojim izveštajima o napretku. ${ }^{44}$ U slučaju Srbije konstatovano je produbljenje izazova u funkcionisanju izbornog postupka, stanju medijskih sloboda, usvajanju i primeni acquis communautaire u domenima vladavine prava, kao i ostvarivanja rezultata u procesu normalizacije odnosa sa vlastima u Prištini (koji su godinu dana bili suspendovani zbog nametanja taksi na uvoz robe iz centralne Srbije). ${ }^{45}$ Uočena je i izvesna dihotomija između ispunjavanja političkih kriterijuma (ograničeni napredak ili bez napretka u odnosu na 2019. godinu, u oblastima u kojima je pripremljenost za članstvo generalno niska) i ekonomske integracije (načinjen određeni napredak i zabeležen uglavnom umereni stepen spremnosti za članstvo u Evropskoj uniji). ${ }^{46}$ Pored drugih konstatovanih manjkavosti uočena je i potreba za unapređenjem administrativnih kapaciteta, kao i što skorijem imenovanju rukovodioca (šefa) pregovarčkog tima, čije je mesto bilo upražnjeno još od ostavke dr Tanje Miščević na tu funkciju 2019. godine. ${ }^{47} \mathrm{U}$ toku 2020. godine nije otvoreno nijedno pregovaračko poglavlje u pregovorima između Evropske unije i Republike Srbije (što nije zabeleženo još od 2014. godine), a prema mišljenju pojedinih predstavnika institucija EU, razlog za to može biti izostanak napretka u suštinski važnim oblastima poput vladavine prava i osnovnih sloboda u odnosu na prethodnu godinu. ${ }^{48}$

Povrh toga, iako je proteklo duže od godinu dana, način primene revidirane metodologije u slučaju Srbije i Crne Gore nije potpuno usaglašen od strane Evropske komisije u trenutku pisanja ovih redova, što predstavlja dodatan

44 "Serbia 2020 Report", European Commission (SWD(2020) 352 final), Brussels, 6. October 2020, pp. 4-5; "Montenegro 2020 Report", European Commission (SWD(2020) 353 final), Brussels, 6. October 2020, pp. 4-6.

45 "Serbia 2020 Report", European Commission (SWD(2020) 352 final), Brussels, 6. October 2020, pp. 4-5.

${ }^{46}$ IIPE, "Annual progress report identifies challenges on Serbia's EU path", China-CEE Institute, Budapest, October, 2020, Vol. 33, No. 4 (RS), 2020, pp. 1-2.

${ }^{47}$ Glas Amerike, Mediji: Tanja Miščević povlači se sa mesta šefice tima za pregovore sa EU, Glas Amerike, 2019, Internet: https://www.glasamerike.net/a/tanja-mi\%C5\%A1\%C4\%8 Devi\%C4\%87-se-povla\%C4\%8Di-sa-mesta-\%C5\%A1efice-tima-za-pregovore-sa-eu/ 5093088.html, 19/02/2021.

${ }^{48}$ European Parliament, 12th EU-Serbia SAPC, 28 January 2021, remote through Interactio, European Parliament, 2021, Internet: https://www.europarl.europa.eu/delegations/en/drs/activities/inter-parliamentary, 10/02/2021. 
izazov. ${ }^{49}$ Strukturu samih klastera sa prikazom do sada otvorenih poglavlja za Republiku Srbiju moguće je videti u tabeli u produžetku. Republika Srbija otvorila je 18 pregovaračkih poglavlja koji su situirani u okviru pet od ukupno šest tematskih klastera tj. oblasti. Fundamentalni, tj. osnovni klaster objedinjuje pet poglavlja u domenima demokratskih institucija, ekonomije, reforme javne uprave i ekonomskih kriterijuma. On poseduje naročitu težinu, budući da celokupni tok pregovora zavisi od napretka u okviru tog klastera (poglavlja 23 i 24, kao "veto poglavlja“, su njegov deo). Budući da Republika Srbija već pregovara po svim poglavljima koja su deo ovog klastera, njegovo otvaranje deluje kao tehnička formalnost. Međutim, u skladu s revidiranom metodologijom politike proširenja, nakon formalnog otvaranja svaki klaster biće podložan principu reverzibilnosti i odlučnijem sankcionisanju u slučaju nazadovanja, uz mogućnost izjašnjavanja država-članica o tome putem obrnute kvalifikovane većine, što može predstavljati izazov. ${ }^{50}$

Prikaz ostvarenog napretka u pristupnim pregovorima Srbije Evropskoj uniji zaključno sa 31.12.2020. ${ }^{51}$

\begin{tabular}{|c|c|c|c|c|c|c|}
\hline $\begin{array}{c}\text { Redni } \\
\text { broj }\end{array}$ & $\begin{array}{c}\text { Šra } \\
\text { oblast }\end{array}$ & $\begin{array}{c}\text { Broj } \\
\text { otvorenih } \\
\text { poglavlja do } \\
31.12 .2020 . \\
\text { godine }\end{array}$ & $\begin{array}{c}\text { Broj } \\
\text { zatvorenih } \\
\text { poglavlja do } \\
31.12 .2020 . \\
\text { godine }\end{array}$ & $\begin{array}{c}\text { Broj } \\
\text { poglavlja u } \\
\text { klasteru }\end{array}$ & $\begin{array}{c}\text { Redni broj i naziv } \\
\text { otvorenih poglavlja }\end{array}$ & $\begin{array}{c}\text { Redni broj i } \\
\text { naziv } \\
\text { neotvorenih } \\
\text { poglavlja }\end{array}$ \\
\hline I & $\begin{array}{c}\text { Osnovni } \\
\text { klaster }\end{array}$ & 5 & 0 & 5 & $\begin{array}{c}\text { (23) Pravosuđe i } \\
\text { osnovna prava, } \\
\text { (24) Pravda, sloboda } \\
\text { i bezbednost, } \\
\text { (5) Javne nabavke, } \\
\text { (18) Statistika, } \\
\text { (32) Finansijska } \\
\text { kontrola }\end{array}$ & / \\
\hline
\end{tabular}

${ }^{49}$ Biljana Baković, Brisel kasni godinu dana s planom za proširenje, Politika, 2021, Internet: http://www.politika.rs/scc/clanak/472918/Brisel-kasni-godinu-dana-s-planom-za-prosirenje, 15/02/2021.

${ }^{50}$ Maja Kovačević, „Politika proširenja Evropske unije u potrazi za reformom”, op. cit., str. 146.

${ }^{51}$ Pregled sačinjen objedinjavanjem podataka iz sledećih izvora: "Enhancing the accession process - A credible EU perspective for the Western Balkans", European Commission 


\begin{tabular}{|c|c|c|c|c|c|c|}
\hline $\begin{array}{l}\text { Redni } \\
\text { broj }\end{array}$ & Šira oblast & $\begin{array}{c}\text { Broj } \\
\text { otvorenih } \\
\text { poglavlja do } \\
31.12 .2020 . \\
\text { godine }\end{array}$ & $\begin{array}{c}\text { Broj } \\
\text { zatvorenih } \\
\text { poglavlja do } \\
31.12 .2020 . \\
\text { godine }\end{array}$ & $\begin{array}{c}\text { Broj } \\
\text { poglavlja } \\
\text { u klasteru }\end{array}$ & $\begin{array}{l}\text { Redni broj i } \\
\text { naziv } \\
\text { otvorenih } \\
\text { poglavlja }\end{array}$ & $\begin{array}{l}\text { Redni broj i } \\
\text { naziv } \\
\text { neotvorenih } \\
\text { poglavlja }\end{array}$ \\
\hline II & $\begin{array}{l}\text { Jedinstveno } \\
\text { tržište }\end{array}$ & 4 & 0 & 9 & $\begin{array}{c}\text { (4):Sloboda } \\
\text { kretanja } \\
\text { kapitala, } \\
\text { (6):Pravo } \\
\text { privrednih } \\
\text { društava, } \\
\text { (7):Pravo } \\
\text { intelektualne } \\
\text { svojine, } \\
\text { (9):Finansijsk } \\
\text { e usluge }\end{array}$ & $\begin{array}{c}\text { (1):Sloboda } \\
\text { kretanja robe, } \\
\text { (2):Sloboda } \\
\text { kretanja } \\
\text { radnika, } \\
\text { (3):Pravo } \\
\text { poslovnog } \\
\text { nastanjivanja i } \\
\text { sloboda } \\
\text { pružanja } \\
\text { usluga, } \\
\text { (8):Politika } \\
\text { konkurencije, } \\
\text { (28):Zaštita } \\
\text { potrošača i } \\
\text { zaštita zdravlja }\end{array}$ \\
\hline III & $\begin{array}{c}\text { Konkurent- } \\
\text { nost i } \\
\text { inkluzivni rast }\end{array}$ & 5 & 2 & 8 & $\begin{array}{c}\text { (17): } \\
\text { Ekonomska i } \\
\text { monetarna } \\
\text { politika, } \\
\text { (20):Predu- } \\
\text { zetništvo i } \\
\text { industrijska } \\
\text { politika, } \\
\text { (25):Nauka i } \\
\text { istraživanje, } \\
\text { (26): } \\
\text { Obrazovanje i } \\
\text { kultura, } \\
\text { (29):Carinska } \\
\text { unija }\end{array}$ & $\begin{array}{c}\text { (10): } \\
\text { Informaciono } \\
\text { društvo i } \\
\text { mediji, } \\
\text { (16): } \\
\text { Oporezivanje, } \\
\text { (19):Socijalna } \\
\text { politika i } \\
\text { zapošljavanje }\end{array}$ \\
\hline
\end{tabular}

(COM(2020) 57 final), Brussels, 2020, p. 8; "Serbia 2020 Report", European Commission (SWD(2020) 352 final), Brussels, 6. October 2020. 


\begin{tabular}{|c|c|c|c|c|c|c|}
\hline $\begin{array}{c}\text { Redni } \\
\text { broj }\end{array}$ & Šira oblast & $\begin{array}{c}\text { Broj } \\
\text { otvorenih } \\
\text { poglavlja do } \\
31.12 .2020 . \\
\text { godine }\end{array}$ & $\begin{array}{c}\text { Broj } \\
\text { zatvorenih } \\
\text { poglavlja do } \\
31.12 .2020 . \\
\text { godine }\end{array}$ & $\begin{array}{c}\text { Broj } \\
\text { poglavlja } \\
\text { u klasteru }\end{array}$ & $\begin{array}{l}\text { Redni broj i } \\
\text { naziv } \\
\text { otvorenih } \\
\text { poglavlja }\end{array}$ & $\begin{array}{l}\text { Redni broj i } \\
\text { naziv } \\
\text { neotvorenih } \\
\text { poglavlja }\end{array}$ \\
\hline IV & $\begin{array}{c}\text { Zelena } \\
\text { agenda i } \\
\text { održiva } \\
\text { povezanost }\end{array}$ & 0 & 0 & 4 & / & $\begin{array}{c}\text { (14): } \\
\text { Transportna } \\
\text { politika, } \\
\text { (15): Energetika, } \\
\text { (21):Trans- } \\
\text { evropske } \\
\text { mreže, } \\
\text { (27): Životna } \\
\text { sredina }\end{array}$ \\
\hline V & $\begin{array}{c}\text { Izvori, } \\
\text { poljoprivreda } \\
\text { i kohezija }\end{array}$ & 2 & 0 & 5 & $\begin{array}{c}(13): \\
\text { Ribarstvo, } \\
\text { (33): } \\
\text { Finansijske i } \\
\text { budžetske } \\
\text { odredbe }\end{array}$ & $\begin{array}{c}\text { (11):Poljoprivre } \\
\text { da i ruralni } \\
\text { razvoj, } \\
\text { (12):Sigurnost } \\
\text { hrane, } \\
\text { veterinarska i } \\
\text { fitosanitarna } \\
\text { politika, } \\
\text { (22):Regionalna } \\
\text { politika i } \\
\text { koordinacija } \\
\text { strukturnih } \\
\text { instrumenata }\end{array}$ \\
\hline $\mathrm{Vl}$ & $\begin{array}{l}\text { Spoljni } \\
\text { odnosi }\end{array}$ & 1 & 0 & 2 & $\begin{array}{c}\text { (30):Spoljni } \\
\text { odnosi, }\end{array}$ & $\begin{array}{c}\text { (31):Spoljna, } \\
\text { bezbednosna i } \\
\text { odbrambena } \\
\text { politika }\end{array}$ \\
\hline / & Izvan klastera & 1 & 0 & 2 & (35):Ostalo & (34):Institucije \\
\hline
\end{tabular}

Dok je u slučaju Crne Gore donekle predvidiva situacija u svetlu činjenice da su pregovori otvoreni u svim pregovaračkim poglavljima (a samim tim i svim tematskim klasterima), u slučaju Srbije nije najjasnije na koji će se način 18 otvorenih pregovaračkih poglavlja transponovati u klastere. Osim birokratske logike - da li se fokusirati na jedini preostali klaster u kojem nijedno poglavlje nije 
otvoreno (br. IV na prikazu), ili pak na one klastere u čijoj se većini poglavlja već pregovora - treba napomenuti da pristupni pregovori predstavljaju i važno sredstvo za političko uslovljavanje, te da možda nije realno očekivati da se u slučaju Srbije gotovo svi klasteri otvore u kratkom roku (bez obzira što i za takva smatranja postoji barem administrativni osnov). Kao srednje rešenje se u medijima polemiše o mogućnosti da Evropska unija, pored otvaranja klastera br. I (osnovna prava), u 2021. razmotri mogućnost otvaranja klastera u domenu zelene agende (u skladu sa strateškim prioritetima aktuelnog saziva Komisije) ili neki od ekonomskih klastera (II/III). ${ }^{52}$ Pored toga, pregovaračke platforme su spremne i čeka se zajednički stav Saveta Evropske unije za sledeća 4 poglavlja: 2 i 3 (u okviru klastera II), i 14 i 21 (klaster IV), dok se za poglavlje 27 (takođe klaster IV) očekuje da Komisija za Savet pripremi nacrt zajedničkog stava. ${ }^{53}$ Međutim, imajući u vidu izostanak napretka ka članstvu Srbije u 2020. godini i najavu kredibilnijeg uslovljavanja kandidata, preduslov za otvaranje bilo kog klastera predstavljaće zabeleženi napredak u oblastima identifikovanim u godišnjem izveštaju o napretku.

Treće - odsustvo povoljnih rezultata, u smislu valorizacije političkog napretka zemalja Zapadnog Balkana ka članstvu u EU, vidljivo je na osnovu niza političkih dokumenata: od godišnjih izveštaja o napretku, preko sadržaja Zagrebačke deklaracije, do neusvajanja zaključaka Evropskog saveta u domenu politike proširenja. Prvo hrvatsko predsedavanje Savetom Evropske unije ostaće upamćeno po eskalaciji pandemije Kovid 19, tokom koje je veći deo kontinenta bio podvrgnut vrlo oštrim ograničavajućim epidemiološkim merama, koje su se odrazile i na (ne)zasedanje nacionalnih i nadnacionalnih institucija. Tako su i godišnji izveštaji o napretku država-kandidata, koji se uobičajeno objavljuju na proleće, usled pandemije pomereni na jesen 2020. godine. Takođe kao posledica ograničavajućih pandemijskih okolnosti, samit „Evropska unija - Zapadni Balkan“, koji je trebalo da predstavlja jedan od centralnih događaja hrvatskog predsedavanja Savetom Evropske unije, umesto u fizičkom obliku održan je u formi video-konferencije. ${ }^{54}$ Pored drugačijeg oblika samog zasedanja, i sam fokus

\footnotetext{
52 Biljana Baković, Brisel kasni godinu dana s planom za proširenje, Politika, 2021, Internet: http://www.politika.rs/scc/clanak/472918/Brisel-kasni-godinu-dana-s-planom-zaprosirenje, 15/02/2021.

53 "Serbia 2020 Report", European Commission (SWD(2020) 352 final), Brussels, 6. October 2020, p. 7.

${ }^{54}$ Goran Bandov, "Croatia's EU Presidency: A strong Europe in a world of challenges", European View, vol. 19, no. 2, 2020, p. 192.
} 
događaja, umesto da obznani snažniju političku nameru za produbljivanje integracije sa zapadnobalkanskim državama (što je bila prvobitna namera), postao je prvenstveno ekonomsko-humanitarne prirode. Verovatno najvažniju zaostavštinu Zagrebačke deklaracije predstavlja sadržaj njenog člana br. 3, u okviru kojeg je najavljeno opredeljivanje 3,3 milijarde evra za finansijsku i drugu podršku prevazilaženja posledica Kovid 19 pandemije..$^{55}$ Većina članova Deklaracije, posredno ili neposredno, poziva na potrebu za bližom saradnjom i solidarnošću tokom pandemijske krize, a premda sintagma "evropska perspektiva“ jeste navedena, ona se spominje svega tri puta u čitavom dokumentu pored niza drugih tema, dok se termin "članstvo" ne spominje nijednom. ${ }^{56}$ Međutim, i pored izostanka spominjanja strateškog političkog cilja - budućeg članstva kandidata u Evropskoj uniji - doprinos tog dokumenta nije bez značaja. Politička relevantnost Zagrebačke deklaracije ogleda se u „podsećanju“ na prepoznatu evropsku perspektivu Zapadnog Balkana na samitima u Zagrebu (2000), Solunu (2003), Sofiji (2018) (član 1), kao i u samoj činjenici da je Samit, uprkos pandemijskim okolnostima, barem nakratko bio u fokusu pažnje predstavnika država-članica, kandidata za članstvo i evropskih institucija.

Evropska unija je usvajanjem izmenjene metodologiju politike proširenja nastojala da osnaži princip uslovljavanja kao najdelotvornijeg alata u pristupnom procesu. Međutim, primeri nezapočetih pristupnih pregovora između EU i Albanije i Severne Makedonije pokazuju da je politika proširenja i dalje u značajnoj meri ostala podložna bilateralnim i proizvoljnim tumačenjima i aktivnostima. Naime, dok je pokretanje pristupnih pregovora godinama odlagano usled nesaglasnosti pojedinih država-članica, pa potom i usled proklamovane neophodnosti da se metodologija politike proširenja unapredi, ni u 2020. godini, kada je usaglašen izmenjeni pristup za taj domen, navedene zemlje-kandidati nisu stupile u pristupni dijalog uprkos prepoznavanju dovoljnog napretka u preobražaju njihovih sistema. ${ }^{57}$ Tako su početkom decembra 2020. predstavnici Bugarske odbili da daju saglasnost za pregovarački okvir koji je

\footnotetext{
${ }^{55}$ Consilium, Zagrebačka deklaracija, 2020, Internet: https://www.consilium.europa.eu/ media/43789/zagreb-declaration-bs-06052020.pdf, 30/01/2021.

56 Ibid.

${ }^{57}$ European Commission, Commission drafts negotiating frameworks for Albania and North Macedonia, European Commssion, 2020, Brussels, Internet: https://ec.europa.eu/ commission/presscorner/detail/en/IP_20_1021, 30/01/2021.
} 
Evropska komisija predložila za Severnu Makedoniju, argumentujući taj akt navodnim prekrajanjem činjenica u tumačenju istorije u toj kandidatskoj zemlji. ${ }^{58}$ Veto bugarske vlade manifestovao se i u neusvajanju godišnjih zaključaka o politici proširenja koje je predložio Savet Evropske unije, što se nikada pre nije desilo i što je predstavljalo nepovoljnu situaciju i za sve druge zapadnobalkanske aktere. $^{59}$ To se negativno odrazilo na ostvarivanje agende Nemačke kao predsedavajuće zemlje Savetom Evropske unije, koja je pokretanje pristupnih pregovora uvrstila među svoje prioritete. ${ }^{60}$ Polovinom decembra delovalo da je spor prevaziđen tokom zasedanja Odbora stalnih predstavnika vlada državačlanica Unije. lako je načelno uvažen bugarski predlog uključivanjem rečenice o „važnosti ugovora Republike Severne Makedonije sa Bugarskom i Grčkom“, čija će primena "dovesti do kraja svih tvrdnji zasnovanih na pogrešnom tumačenju istorije", usvajanje Zaključaka je ponovo onemogućeno. Naime, ambasadori Češke i Slovačke pri Odboru usprotivili su se sintagmi o „pogrešnom tumačenju istorije“" navodeći da EU ne može biti merodavna da procenjuje aspekte koji se odnose na istoriju ili identitetska pitanja. ${ }^{61}$ Autori ovog rada konstatuju da su predstavnici Slovačke i Češke poslali trojaku poruku: (1) da je neprimereno da evropske institucije evaluiraju kako istorija treba da bude tumačena; (2) da je uključivanje predloženih rečenica u neskladu sa samim razvojem Unije kao projekta osiguranja mira i pomirenja među susedima; (3) da izjašnjavanje o takvim pitanjima može predstavljati negativan presedan u smislu podsticanja primene veto klauzule u slučaju bilateralnih razmirica. Međutim, bez obzira da li se po mišljenju autora možda radilo o donekle iznuđenoj meri srednjoevropskih zemalja, ishod je takav da zaključci Saveta za proširenje i

58 Una Hajdari, Tongue-tied: Bulgaria's language gripe blocks North Macedonia's EU path, Politico, 2020, Internet: https://www.politico.eu/article/bulgaria-north-macedonia-euaccession-talks-language-dispute/, 20/02/2021.

${ }^{59}$ Radio Slobodna Evropa, Zaključci o Zapadnom Balkanu nisu usvojeni, Radio Slobodna Evropa, 2020, Internet: https://www.slobodnaevropa.org/a/31005700.html, 01/02/2021.

${ }^{60}$ Marta Szpala \& Mateusz Seroka, Bulgaria blocks accession negotiations with North Macedonia, OSW, 2020, Internet: https://www.osw.waw.pl/en/publikacje/analyses/202012-14/bulgaria-blocks-accession-negotiations-north-macedonia, 15/02/2021.

${ }^{61}$ European Western Balkans, The Czech Republic and Slovakia have blocked EU Council conclusions on enlargement, EWB, 2020, Internet: https://europeanwesternbalkans.com/ 2020/12/18/the-czech-republic-and-slovakia-have-blocked-eu-council-conclusions-onenlargement/, 19/02/2021. 
procesa stabilizacije i pridruživanja za 2020. nisu usvojeni, što je poslalo obeshrabrujuću poruku vladama i građanima na Zapadnom Balkanu na završetku prve pandemijske godine.

\section{Zaključak}

Nepovoljan tok pandemije u značajnoj meri razotkrio je ranjivosti političkih i ekonomskih sistema u regionu Zapadnog Balkana i zaustavio brojne razvojne procese. Epidemiološki izazov duboko je uticao i na domen unutrašnje (ne)jedinstvenosti i (ne)solidarnosti na prostoru Evropske unije, a dovedena je u pitanje i njena sposobnost da bude predvodnica u vremenima krize. Među izazove sa kojima se EU suočila je i pojačano prisustvo drugih međunarodnih aktera na prostoru Zapadnog Balkana, što je i posledica odložene, nedovoljne i delimično neprimerene reakcije Evropske unije u pojedinim periodima krizne 2020. godine (npr. prilikom obustavljanja izvoza medicinske opreme u region obuhvaćen politikom proširenja u početnoj fazi pandemije).

Početkom 2020. godine usvojena je izmenjena metodologije politike proširenja Evropske unije $s$ fokusom na unapređenju kredibilnosti pristupnog procesa, jačeg angažovanja političkih elita, grupisanja pregovaračkih oblasti u tzv. „klastere" i većoj predvidivosti procesa. Na taj način EU je demonstrirala spremnost da inovira svoj pristup, čije su prethodne manjkavosti otežavale produbljivanje odnosa sa zapadnobalkanskim zemljama. Revidirana metodologija u većoj meri potencira i mogućnost primene instrumenta reverzibilnosti, odnosno negativnog uslovljavanja u slučaju nazadovanja u reformskom procesu. Prethodno navedeni elementi imaju dvojaki značaj: usmereni su ka osnaživanju principa uslovljavanja kao najdelotvornijeg sredstva politike proširenja, ali i ka vrednovanju napora onih kandidata koji su napredovali (ili pak nazadovali) u ispunjavanju reformske agende. Međutim, postoji opravdana bojazan da podložnost političkim tumačenjima koje nemaju puno veze sa preobražajnim tokom u okviru evropskih integracija (kao što je slučaj u aktuelnim makedonsko-bugarskim odnosima), princip reverzibilnosti može da učini još jednim dodatnim instrumentom za držanje zemalja-kandidata na distanci.

Dok je logika sankcionisanja nazadovanja povezana sa osnaživanjem kredibilnosti principa uslovljavanja, treba imati u vidu da je neophodno da se dodatno omogući i veći stepen izvesnosti nagrađivanja za preduzete reforme. 
Odlaganje početka pristupnih pregovora između EU i Severne Makedonije, nažalost, svedoči da se princip uslovljavanja i dalje koristi arbitrarno od strane država-članica, a da kontinuirano produbljivanje reformskih procesa ne mora da ishoduje povoljnom valorizacijom napretka ka članstvu. Bilans revidirane metodologije tek će $u$ kasnijoj fazi moći da bude predmet akademske analize, $s$ obzirom na to da se u trenutku pisanja ovih redova ona i dalje ne primenjuje. Dok je prethodna godina počela u znaku izmenjene metodologije koja je trebalo da revitalizuje politiku proširenja, njen završetak - neusvajanje godišnjih zaključaka Saveta za proširenje i procesa stabilizacije i pridruživanja - poslalo je pesimističnu poruku za „evropsku perspektivu“ Zapadnog Balkana. Jedan od mogućih načina za prevazilaženje situacija koje ometaju pristupni proces kandidata za članstvo moglo bi da bude i uspostavljanje nezavisne institucije koja bi posredovala u diplomatskim sporovima. ${ }^{62}$ Međutim, kako je korišćenje bilateralnog uslovljavanja kao instrumenta za rešavanje sporova u korist državačlanica prisutno još od prvog proširenja Evropske zajednice (npr. višegodišnje onemogućavanje pristupanja Ujedinjenog Kraljevstva od strane Francuske koje je trajalo do 1973. godine), ne deluje ostvarivo da članice odluče da upostavljanjem nove institucije umanje mogućnost direktnog uticaja na pristupni postupak trećih zemalja. ${ }^{63}$

Kako bi u 2021. godini stagniranje moglo da se pretvori u napredak u smislu formalnog otvaranja pregovaračkih klastera u slučaju Republike Srbije, nužno je da institucije preduzmu korake u osnovnim pitanjima koja su prepoznata u Izveštaju o napretku, među kojima se izdvajaju domeni poput unapređenja izbornog procesa, stvaranja nezavisnijeg pravosudnog sistema (uključujući i nužnost ustavnih promena), kao i oblastima poput primene usvojene medijske strategije i osposobljavanja održivog mehanizma za borbu protiv korupcije. ${ }^{64}$ Pored toga, podrazumeva se i dalji angažman u dijalogu o normalizaciji odnosa između Beograda i Prištine, koja pored domena vladavine prava i nezavisnog

${ }^{62}$ Erwan Fouéré, The EU's enlargement agenda is no longer fit for purpose, CEPS, 2021, Internet: https://www.ceps.eu/the-eus-enlargement-agenda-is-no-longer-fit-for-purpose/, 30/01/2021.

${ }^{63}$ Miloš Petrović, „Bregzit kao ishod ambivalentne britanske politike prema evropskoj integraciji", Međunarodni problemi, vol. LXXII, br. 3, 2020, str. 537-538.

64 IIPE, Annual progress report identifies challenges on Serbia's EU path, op. cit., 2020, pp. 1-4. 
pravosuđa predstavlja prioritetan aspekt vrednovanja reformskog procesa Srbije u kontekstu pristupanja Evropskoj uniji.

Međutim, pored kriterijuma koje Srbija i druge zemlje-kandidati treba da zadovolje kako bi proces evropskih integracija napredovao ka članstvu, postoje i izazovi u Evropskoj uniji u pogledu davanja veće prioritetnosti politici proširenja. Politički akti poput godišnjih izveštaja o napretku kandidata za članstvo (koji su objavljeni sa kašnjenjem usled pandemije), potom tekst Zagrebačke deklaracije koji uzgredno spominje "evropsku perspektivu“ regiona, pa i neusvajanje zaključaka Evropskog saveta u domenu politike proširenja, vode zaključku da u pandemijskoj godini ne samo da nije bilo vidljivog napretka na evropskom putu zemalja regiona, već i da perspektiva pristupanja deluje čak i dalje nego što je to bio slučaj pre aktuelne krize. Ne samo da u trenutku pisanja ovih redova nije izvesno kako će se u birokratskom smislu transponovati otvorena poglavlja u klasterske oblasti (npr. u slučaju Srbije), već nije poznato ni u kojim terminima će se odvijati ključni procesi u smislu evaluacije napretka kandidata za članstvo, imajući u vidu da pandemijske okolnosti, nažalost, i dalje predstavljaju značajan izazov funkcionisanju različitih politika Evropske unije. Aktuelna godina predstavlja produžetak pandemijske 2020, koja je protekla u znaku ambivalentnih odnosa između zemalja Zapadnog Balkana i Evropske unije. Kao i u drugim trenucima pandemijske krize, akteri poput Kine ili Rusije deluju prisutnije na Zapadnom Balkanu nego Evropska unija, što je ponovo vidljivo u kontekstu početka masovne imunizacije stanovništva vakcinama protiv Kovid 19. Težnja za jačim geopolitičkim prisustvom Evropske unije u njenom geografskom susedstvu nije ostvarena u 2020. godini, a u politici proširenja ni u toj godini nije došlo do unapređenja odnosa sa zapadnobalkanskim kandidatima za članstvo. Kako bi revidirana metodologija politika proširenja zaista mogla da bude smatrana verodostojnijom, nužno je da se u narednih nekoliko godina pokaže da je Evropska unija sposobna da upravlja procesom evropeizacije Zapadnog Balkana, i to na način koji podstiče i ohrabruje preobražajne demokratske tokove, kao što je to bio slučaj u ranijim ciklusima „istočnih“ proširenja.

\section{Literatura}

Bandov, Goran, "Croatia's EU Presidency: A strong Europe in a world of challenges", European View, vol. 19, no. 2, 2020, p. 192. 
Borneman, John \& Fowler, Nick, "Europeanization", Annual Review of Anthropology, vol. 26, 1997.

Börzel, Tanja, "When Europeanization Hits Limited Statehood - The Western Balkans as a Test Case for the Transformative Power of Europe", KFG Paper series, no. 30, 2011.

Economides, Spyros \& Ker-Lindsay, James, “Pre-Accession Europeanization': The Case of Serbia and Kosovot", Journal of Common Market Studies, vol. 53, no. 5, 2015.

Frontini, Andrea \& Denti, Davide, "Italy and EU enlargement to the Western Balkans: the Europeanization of national interests?", Southeast European and Black Sea Studies, vol. 17, no. 4, 2017.

Kovačević, Maja, Evropska diferencirana unija, Fakultet političkih nauka, Beograd, 2020.

Kovačević, Maja, „Politika proširenja Evropske unije u potrazi za reformom“, Politička revija, no. 2/2020, 2020.

Lehne, Stefan, "Geopolitics, the EU and the Western Balkans", in: Zoran Nechev (ed), Stimulating strategic autonomy-Western Balkans' contribution for a shared European Future, Institute for Democracy Societas Civilis, Skopje, 2020.

Murphy, Mary, "The Brexit crisis, Ireland and British-Irish relations: Europeanisation and/or de-Europeanisation?" Irish Political Studies, vol. 34, no. 4, 2019.

Noutcheva, Gergana \& Aydin-Düzgit, Senem, "Lost in Europeanisation: The Western Balkans and Turkey", West European Politics, vol. 35, no. 1, 2012.

Petrović, Miloš, „Bregzit kao ishod ambivalentne britanske politike prema evropskoj integraciji", Međunarodni problemi, vol. LXXII, br. 3, 2020.

Petrović, Miloš, "EU integration process of Serbia: a vicious circle of high politics?" The Review of International Affairs, vol. LXX, no. 1175, 2019.

Petrović, Miloš, „Izmenjena politika proširenja: izazovi i koncentrični krugovi integracije", Međunarodni problemi, vol. LXXI, no. 1/2019, 2019.

Tzifakis, Nikolaos, "The Western Balkans during the pandemic: Democracy and rule of law in quarantine?" European View, vol. 19, no. 2, 2020. 
Vučković, Vladimir \& Đorđević, Vladimir (eds.), Balkanizing Europeanization: Fight against corruption and regional relations in the Western Balkans, Peter Lang, Berlin, 2019.

Zhelyazkova, Asya (et al.), "European Union Conditionality in the Western Balkans: External Incentives and Europeanisation", in: Jelena Dzankic, Soeren Keil \& Marko Kmezić (eds.), The Europeanisation of the Western Balkans A Failure of EU Conditionality?, Palgrave Macmillan, 2019.

\section{COVID-19-A DISRUPTIVE FACTOR IN CLOSER BONDING BETWEEN THE EUROPEAN UNION AND THE WESTERN BALKAN REGION}

Abstract: In the context of this paper, the wider focus will be on the European Commission's proclamation of the need for greater geopolitical engagement in the Western Balkan region. Although the European Union has for years been advancing its relations with those countries by employing the enlargement policy instruments, during the past several years, other geopolitical actors have also been similarly engaged in that region, which has not been beneficial for the EU-Western Balkan cooperation. Despite the numerous international challenges for the EU, the authors consider that through the adoption of the revised enlargement methodology, the European Union has demonstrated a political willingness to advance its cooperation with that region. However, the extraordinary circumstances caused by the COVID19 pandemic, which ensued from the first quarter of 2020, have thenceforth marginalized the enlargement policy. The authors conclude that the pandemic's unfavourable trajectory has had a negative impact on EU-Western Balkan relations, both directly and indirectly. By using context analysis and the Europeanisation theoretical approach, the authors identify several layers of political damage caused by the pandemic: 1 . the delayed EU support in overcoming the consequences, which has negatively affected its soft power and credibility, but also provided additional space for the engagement of other actors; 2 . the lack of focus and inertia of state institutions in certain candidate countries when it comes to deepening of the transformative democratic processes; and 3. the absence of favourable outcomes in terms of political progress towards EU membership, which is also visible based on the content of the Zagreb Declaration (2020) and the failure to adopt the European Council conclusions on the enlargement policy.

Keywords: revised enlargement methodology, European Union, membership candidates, COVID-19, challenges, Europeanisation, Western Balkans. 